\title{
Optimal Type 2 Diabetes Mellitus Management and Active Ageing
}

\author{
Alessia Maria Calabrese, Valeria Calsolaro, Sara Rogani, Chukwuma Okoye, Nadia Caraccio and Fabio Monzani *
}

check for updates

Citation: Calabrese, A.M.; Calsolaro, V.; Rogani, S.; Okoye, C.; Caraccio, N.; Monzani, F. Optimal Type 2 Diabetes Mellitus Management and Active Ageing. Endocrines 2021, 2, 523-539. https://doi.org/10.3390/

endocrines 2040047

Academic Editor: Antonio Brunetti

Received: 1 August 2021

Accepted: 2 December 2021

Published: 13 December 2021

Publisher's Note: MDPI stays neutral with regard to jurisdictional claims in published maps and institutional affiliations.

Copyright: (C) 2021 by the authors. Licensee MDPI, Basel, Switzerland. This article is an open access article distributed under the terms and conditions of the Creative Commons Attribution (CC BY) license (https:// creativecommons.org/licenses/by/ $4.0 /)$.
Geriatrics Unit, Department of Clinical and Experimental Medicine, University of Pisa, 56125 Pisa, Italy; alessiamariacalabrese@gmail.com (A.M.C.); v.calsolaro@ao-pisa.toscana.it (V.C.); sara_rogani@hotmail.it (S.R.); chuma@hotmail.it (C.O.); nadiacaraccio.amb@libero.it (N.C.)

* Correspondence: fabio.monzani@unipi.it; Tel.: +39-3337733135

\begin{abstract}
Type two diabetes mellitus (T2DM) represents a chronic condition with increasing prevalence worldwide among the older population. The T2DM condition increases the risk of micro and macrovascular complications as well as the risk of geriatric syndromes such as falls, fractures and cognitive impairment. The management of T2DM in the older population represents a challenge for the clinician, and a Comprehensive Geriatric Assessment should always be prioritized, in order to tailor the glycated hemoglobin target according to functional and cognitive status comorbidities, life expectancy and type of therapy. According to the most recent guidelines, older adults with T2DM should be categorized into three groups: healthy patients with good functional status, patients with complications and reduced functionality and patients at the end of life; for each group the target for glycemic control is different, also according to the type of treatment drug. The therapeutic approach should always begin with lifestyle changes; after that, several lines of therapy are available, with different mechanisms of action and potential effects other than glucose level reduction. Particular interest is growing in sodium-glucose cotransporter-2 inhibitors, due to their effect on the cardiovascular system. In this review, we evaluate the therapeutic options available for the treatment of older diabetic patients, to ensure a correct treatment approach.
\end{abstract}

Keywords: type 2 diabetes mellitus (T2DM); older people; frailty; antidiabetic drugs; comprehensive geriatric assessment; therapeutic targets; hypoglycemia

\section{Introduction}

The prevalence of type 2 diabetes mellitus (T2DM) among older people is growing in relation to an ageing global population. According to the latest data of the International Diabetes Federation (IDF), in 2019 the prevalence of diabetes in people older than 65 years was around 19\%; thus, over 130 million older adults were affected by diabetes with an estimated further increase to 276.2 million by 2045 [1].

Beyond the higher risk of well-known macrovascular and microvascular complications [2], older adults with diabetes are also at greater risk of geriatric syndromes compared to non-diabetic. As a matter of fact, due to pain, impaired vision, and motor and sensory neuropathy, T2DMis associated with 64\% increased risk of falls (in particular for patients treated with hypoglycemic drugs such as insulin) [3], and fragility fractures [4].

Older people with T2DM are more likely to develop cognitive impairment, ranging from mild cognitive impairment (MCI) to overt dementia [5], and both hypo- and hyperglycemia seem to be related to neurocognitive dysfunction [6,7].

Moreover, the high prevalence of urinary incontinence, chronic pain $[2,8]$, delirium $[9,10]$ and depression $[2,8,9]$ among diabetic older adults negatively affects the quality of life.

These conditions, along with compliance issues, polypharmacy and, often, inadequate hydration and nutrition, have a negative impact on older adults' functional status, leading to higher risk of disability and institutionalization $[2,8,9,11]$. 
Optimal T2DM management in older people represents a challenge, given the extreme heterogeneity of this population in terms of functional and cognitive status, comorbidities and life expectancy, and a comprehensive geriatric assessment (CGA) should always be performed in order to assess the best therapeutic approach.

The diagnosis of diabetes has always been focused on hyperglycemia and for many years insulin resistance was considered the primary etiological factor for the development of type 2 diabetes, with hyperinsulinemia representing a compensatory mechanism to overcome systemic insulin resistance. Nevertheless, several recent studies support the hypothesis that hyperinsulinemia is the primary mechanism underlying type 2 diabetes, besides being an important etiological factor for the development of metabolic syndrome, obesity, cardiovascular disease, cancer and premature mortality. According to this new perspective, therapeutic approaches should aim at reducing plasma insulin concentrations. While at the late stage of the disease most patients may require exogenous insulin therapy to achieve optimal glucose control, it could be harmful to administer insulin in the early stages of the disease characterized by elevated concentration of fasting insulin levels. Strategies for managing hyperinsulinemia, such as caloric restriction, together with drugs reducing insulin hyper secretion or increasing insulin hepatic clearance and insulin sensitivity, are among the new potential strategies for the management of T2DM and may also have the potential to prevent or delay the progression of the disease [12,13]. In this review, we discuss CGA-based treatment goals in older people and evaluate the current antidiabetic therapies.

The search was conducted in PubMed, with the keywords "Diabetes mellitus, older people, older patients, antidiabetics, metformin, gliflozins, insulin, DPP4-I, GLP-1R agonists"; metaanalysis, randomized clinical trials, reviews and abstracts in English published within the last 10 years were selected and reviewed. We also included current guideline recommendations.

\section{Type 2 Diabetes Mellitus: Treatment Targets}

Despite the heavy social and economic burdens, the older diabetic population (especially with higher degree of frailty) has been historically underrepresented in clinical randomized trials [14-16], though, in the last 15 years, several organizations have endorsed the concept of tailored diabetes care on the basis of functional status, life-expectancy and risk of drug-induced hypoglycemia.

The glycated hemoglobin (HbA1c) level generally recommended in older adults receiving antidiabetic drugs not associated with hypoglycemia is $<7.5 \%$. This value is consistent with what is recommended for younger people by the current standards of care of the American Diabetes Association (ADA) [17] and the International Diabetes Federation (IDF) [18].

Nevertheless, this is a simplified vision of clinical decision-making; as a matter of fact, older adults should be further classified through CGA, especially older patients receiving insulin or other drugs potentially associated with hypoglycemia.

According to ADA, older adults with diabetes can be categorized into three groups: healthy patients with good functional status, patients with complications and reduced functionality and vulnerable patients at the end of life. The first group includes patients with few comorbidities, good cognitive and functional status and long-life expectancy and may be treated using therapeutic strategies and targets similar to those for young diabetic adults, aiming for values of $\mathrm{HbA} 1 \mathrm{c}<7-7.5 \%$, fasting or pre-prandial glucose $80-130 \mathrm{mg} / \mathrm{dL}$ and bedtime glucose $80-180 \mathrm{mg} / \mathrm{dL}$. Patients with at least three coexisting chronic illnesses, cognitive or functional impairment or advanced diabetes complications belong to the second group and may benefit from less stringent glycemic control ( $\mathrm{HbA} 1 \mathrm{c}<8 \%$, fasting or pre-prandial glucose 90-150 mg/dL, bedtime glucose 100-180 mg/dL).

The latter group comprises older adults receiving palliative care and end-of-life care, and/or with cognitive or functional disability. For such patients, physicians should apply strategies to preserve quality of life, avoid hypoglycemia and symptomatic hyperglycemia (avoiding reliance on $\mathrm{HbA1c}$, fasting or pre-prandial glucose 100-180 mg/dL, bedtime glucose 110-200 mg/dL). 
Some patients will not fit into a particular category, and it will be necessary to draw up individualized care plans. Patient and caregiver preferences should always be considered and periodically reassessed, together with health status, in order to adapt to changes over time [17]. In line with ADA, IDF identified three main categories of older adults with diabetes. The first is characterized by people functionally independent with a $\mathrm{HbA} 1 \mathrm{c}$ target of $7-7.5 \%$. The second group includes functionally dependent people with higher risk of hypoglycemia or hyperglycemia, poor self-management ability and increased risk of hospitalization. For such individuals, the recommended target of HbA1c is $7-8.5 \%$, avoiding drugs that might cause nausea or gastrointestinal disorders and drugs with increased risk of hypoglycemia. The third category consists of patients approaching the end of life, therefore the main goal is to avoid symptomatic hypo- and hyperglycemia, considering withdrawal of therapy (including insulin) [18]. Treatment goals according to patients' functional status and guidelines are summarized in Table 1.

Table 1. Treatment goals for glycemia in older adults with diabetes.

\begin{tabular}{|c|c|c|c|}
\hline & $\begin{array}{c}\text { Healthy (Few Coexisting Chronic } \\
\text { Illnesses, Intact Cognitive and } \\
\text { Functional Status), Long Life } \\
\text { Expectancy }\end{array}$ & $\begin{array}{l}\text { Complex/Intermediate (Multiple } \\
\text { Coexisting Chronic Illnesses, } \\
\text { Functional Impairments, Mild to } \\
\text { Moderate Cognitive Impairment) }\end{array}$ & $\begin{array}{l}\text { Very Complex/Poor Health } \\
\text { (Long-Term Care or End-Stage } \\
\text { Chronic Illnesses, Moderate to } \\
\text { Severe Cognitive Impairment), } \\
\text { Approaching to End of Life }\end{array}$ \\
\hline $\begin{array}{c}\text { ADA } 2021 \\
\text { [17] }\end{array}$ & $\begin{array}{l}\qquad \mathrm{HbA} 1 \mathrm{c}<7-7.5 \% \\
\text { Fasting glucose } 80-130 \mathrm{mg} / \mathrm{dL} \\
\text { Bedtime glucose } 80-180 \mathrm{mg} / \mathrm{dL}\end{array}$ & $\begin{array}{l}\text { HbA1c }<8 \% \\
\text { Fasting glucose } 90-150 \mathrm{mg} / \mathrm{dL} \\
\text { Bedtime glucose } 100-180 \mathrm{mg} / \mathrm{dL}\end{array}$ & $\begin{array}{l}\text { Avoid symptomatic hypo- and } \\
\text { hyperglycemia } \\
\text { Avoid reliance on } \mathrm{HbA} 1 \mathrm{c} \\
\text { Fasting glucose } 100-180 \mathrm{mg} / \mathrm{dL} \\
\text { Bedtime glucose } 110-200 \mathrm{mg} / \mathrm{dL}\end{array}$ \\
\hline IDF [18] & $\mathrm{HbA} 1 \mathrm{c} 7-7.5 \%$ & $\mathrm{HbA} 1 \mathrm{c} 7-8 \%$ & $\begin{array}{l}\text { Avoid symptomatic hypo- and } \\
\text { hyperglycemia, consider } \\
\text { withdrawal of therapy }\end{array}$ \\
\hline
\end{tabular}

Abbreviations. T2DM: Type 2 Diabetes Mellitus. ADA: American Diabetes Association. IDF: International Diabetes Federation. HbA1c: glycated hemoglobin.

It is extremely important, however, to consider the potential limitations of $\mathrm{HbA1c}$. Even though the measurement of HbA1c is the standard biomarker for glycemic control, it may not be reliable in particular situations such as anemia or other conditions that influence red blood cell turnover (hemoglobinopathies, hemodialysis, recent transfusions, erythropoietin therapy, chronic liver diseases). In these settings, capillary glucose or continuous glucose monitoring (CGM) should be used [19].

Hypoglycemia is a frequent occurrence in diabetic patients treated with insulin or insulin secretagogues and remains the most alarming complication of diabetes management, since it is associated with an increased morbidity and mortality risk. Hypoglycemia can lead to serious outcomes, such as coma and death, can limit the independence and autonomy of patients and has a significant effect on the quality of life of patients. Repeated episodes of hypoglycemia can lead to "hypoglycemia unawareness" defined as the onset of neuroglycopenic symptoms (weakness, tiredness, dizziness, difficulty with concentration, seizures, coma) before the appearance of autonomic warning symptoms, due to the shift of the glycemic threshold for counter regulation to lower plasma glucose concentration. Polypharmacy can also increase the risk of hypoglycemia unawareness, especially in elderly patients treated with insulin or insulin secretagogues and beta-blockers [20-22].

In order to improve clinical outcomes, educational programs should be patient- and caregiver-centered. Information and instructions should always be given in a clear and simple way. Patients and caregivers should be trained to recognize signs and symptoms of hypoglycemia and should be encouraged always to have glucose or carbohydrate containing food at their disposal. The number of daily glucose checks should be assessed in relation to the antidiabetic drug, keeping a record of blood sugar to show to the healthcare team, even via telemedicine $[18,23,24]$. 


\section{T2DM Treatment Options in Older Patients Lifestyle Changes}

Similarly to younger patients, lifestyle modification should be considered as a primary goal in the general population; moreover, it represents the first-line treatment of T2DM in older adults $[17,18,25,26]$.

One of the primary causes of T2DM, at least in the Western Countries, is believed to be the energy-dense diet and sedentary life, directly responsible also for the obesity surge. However, the increased visceral obesity, rather than the higher BMI, seems to be related to T2DM development [27]. Diet is certainly one of the most involved factors in T2DM development; as a general view, refined grains and sugar sweetened drinks are associated with higher risk of diabetes, and daily nuts consumption seems to be somehow protective [27-29]. Studies aiming at investigating diet impact on the risk of diabetes are widely available. It is important to notice that several dietary studies showed improvement in metabolic control, which could actually be due to the behavioral changes in at least the first phases of the study, when the volunteers change eating habit and lose weight as a possible "study effect" [27]. Unfortunately, poor compliance has been seen in long-term studies, but few studies have been conducted with interesting results. In particular, the PREDIMED trial evaluated the incidence of diabetes comparing the Mediterranean diet supplemented with either olive oil or nuts compared to a low fat diet [30]. In the study, 418 non-diabetic patients (aged 55-80) were enrolled and divided into low fat diet and Mediterranean diet (a group supplemented with olive oil and a group with nuts). After 4 years follow up, the incidence of T2DM was $10.1 \%$ and $11 \%$ in the Mediterranean diet with olive oil or nuts, respectively, and 19.9\% in the low-fat diet group. The incidence of diabetes was reduced by $52 \%$ in the Mediterranean diet group (olive oil and nuts pooled together) as compared to the control group [30]. The study, which did not have any weight loss requirement or outcome, suggested that some components of the Mediterranean diet would help in decreasing the risk of developing diabetes.

Nutritional status should always be assessed on admission and then periodically with the purpose of drawing up an individualized nutrition plan. In overweight/obese patients with high functional status, a $5-7 \%$ weight loss should be promoted in order to improve glycemic control [31].

Patients with a higher degree of frailty should follow a diet rich in protein and energy to prevent malnutrition and weight loss [32].

Strict dietary restrictions should be avoided in older adults with severe comorbidities and cognitive or functional disability $[17,18,26]$.

Greater interest has been shown towards low carbohydrate diets, and clinical trials with up to two years follow up have shown that low carbohydrate diets have beneficial effects on cholesterol and glucose metabolism [33,34]. In the single harm 1-year longitudinal study evaluating the outcome of a low carbohydrate diet in T2DM patients, performed following a training digital program, the group completing the study had reduced $\mathrm{HbA1c}$ levels, and the use of glucose-lowering medication was also reduced [35]. In the Participant experiences in the Diabetes REmission Clinical Trial (DiRECT), a cohort of 280 patients (aged 20-65 years) from Clinical Practices in UK received either the usual care or a weight management program, including low calories diet replacement, food reintroduction and long term weight loss maintenance, aiming at reducing both weight and $\mathrm{HbA1c}$ [35].The results from this study showed that, at 12 months, significant weight loss was achieved in the intervention group [36], with $46 \%$ of diabetes remission compared to the $4 \%$ in the control group (odds ratio 19.7, 95\% CI 7.8-49.8; $p<0.0001$ ). Quality of life also improved in the intervention group. In a narrative review including 99 articles on diabetes remission or reversal, three strategies have been evaluated: bariatric surgery, suggested to treat morbid obesity and subsequent diabetes, low-calories diets and carbohydrate restriction. Among them, bariatric surgery showed early resolution of the comorbidities linked to obesity, but the results, in terms of T2DM, were less durable in the long term [37]. Low calories diet was proven effective in reversing diabetes in the short term, especially in patients 
with a recent diagnosis; however, severe energy restriction is concerning in the long term, because of potential changes in body composition, metabolic adaptation and subsequent weight gain [37]. Carbohydrate restricted diet, aiming at inducing ketosis, determined improvement in $\mathrm{HbA} 1 \mathrm{c}$ levels and reduction of hypoglycemic medications, together with improvement in several cardiovascular risk factors. The improvement was sustained over time, for up to two years [38]. It has to be considered that the studies were not conducted on an older population, thus representing interesting and promising strategies for a healthier ageing, when applied in the younger phases of life, and should be avoided in frail older subjects [39]. As general advice, a careful evaluation of the macro/micronutrients intake is recommended, and should be applied in the older population, either with or without diabetes. The European Guidelines on Clinical Nutrition and metabolism in geriatric patients recommend an energy intake of $30 \mathrm{kcal} / \mathrm{kg}$, to be adapted basing on physical activity, nutritional status, and tolerance; certainly, this consideration could be applied to elderly patients with diabetes [40]. Protein intake should be at least $1.0 \mathrm{~g} / \mathrm{kg}$ body weight/day, up to $1.2-1.5 \mathrm{~g} / \mathrm{kg}$ body weight/day in older subjects with acute or chronic illnesses; higher protein intake seems to be associated with lower incidence of frailty and better gait speed [41]. In a three-year follow up study in a population of older diabetic patients, a protein intake higher than $1 \mathrm{~g} / \mathrm{kg}$ of body weight/day resulted in better physical strength, compared to patients with lower intake [42]. Ensuring sufficient intake of vitamins, and in particular vitamin $\mathrm{D}$, is also an important strategy to prevent frailty and muscle strength loss. Together with vitamin $\mathrm{D}$, monitoring of vitamin $\mathrm{B} 12$, and consequent replacement whenever necessary, is suggested, since vitamin B12 deficiency is frequent among diabetic patients, especially when treated with Metformin, particularly in the more advanced age stages $[43,44]$.

The risk of frailty and sarcopenia is also increased by high intake of saturated fatty acids; on the contrary, polyunsaturated fatty acids (PUFAs), and in particular omega-3 fatty acids, reduce plasma triglyceride levels, as well as oxidative markers, and was proven effective in improving muscle strength, grip and gait speed [42].

Together with diet and weight control, physical activity has to be considered a fundamental core feature to ensure healthy ageing, not only for diabetic patients. Of particular importance is the maintenance of balance and muscle strength, to avoid falls and fractures and preserve independence in the activities of daily living [45]. Even though several training programs have been tested and proven useful, their systematic use in clinical practice is still lacking [45]. Natovich et al. conducted a feasibility study to test the efficacy of multidisciplinary intervention carried out by a team of diabetic nurse, dietitian, diabetes specialist, neuropsychologist and physiotherapist in older diabetic patients with reduced cognitive performance [46]. In their study, the intervention group went through an intensive phase, with weekly meetings for cognitive and physical training as well as tasks to conduct at home, and a consolidation phase, with monthly meeting to discuss implementation of the strategies. Aerobic capacity, balance and risk of fall indices were improved after only months, with some persisting at 12 months [46].

Functionally independent older adults should be encouraged to perform moderate aerobic activity of at least $30 \mathrm{~min}$ for 5 days each week $[17,18,25,26]$. Prior to physical activity, exercise capacity, blood pressure and heart rate should be evaluated, and further test should be performed in patients at high risk of cardiovascular disease.

In addition to the lifestyle changes, diet and exercise, the education of patients and caregivers for a successful self-management of diabetes should be regarded as a goal and as an actual part of the therapy and has been widely recommended [1,47]. Educational programs have been set up over the last few years, and included in national guidelines, with further implementation for relatives' education, such as the DiaLife program [47]. In UK, the DESMOND (Effectiveness of the diabetes education and self-management for ongoing and newly diagnosed) program was designed to educate people with newly diagnosed diabetes and to evaluate the possible advantages in lifestyle, psychological, social and biochemical measures, vs. standard care [48]. The program's advantages were 
seen in terms of improvement in lifestyle and perception of the disease, but not in glycated hemoglobin values [48]. Very recently, the feasibility of the program was extended to low-to-middle income countries, and the results were promising [49], underlying how important a systematic approach would be in general practice.

Diabetes and sleep are intricately connected, and sleep disturbances appear to play a role in the development of T2DM. Over the last decade, several studies have examined the association between sleep quantity and/or quality with glycemic control in patients with T2DM. Poor sleep habits and sleep disorders, as well as altered sleep duration, are associated with higher $\mathrm{HbA1c}$ levels among adults with type 2 diabetes [50,51]. A recent meta-analysis examined the correlation between sleep duration and risk for type 2 diabetes. Both short and long sleep duration have been linked to poor health outcomes and to a significantly increased risk of type 2 diabetes, suggesting a possible role of sleep disturbances in the pathophysiological changes predisposing to diabetes [52,53]. In observational studies, insufficient sleep duration and/or sleep disorders such as insomnia and obstructive sleep apnea have all been associated with higher risk of type 2 diabetes. Beyond the duration of sleep, the timing of sleep (morningness or eveningness chronotypes), controlled by the circadian clock and depending on genetic and age-related factors, also has a significant impact in T2DM development [54]. These findings underscore the importance of appropriate sleep duration in the delay or prevention of type 2 diabetes.

Nowadays, more and more older people are still working, since retirement age has increased over the past decades. While working at older age has been shown to have benefits on mental health, the stress of undertaking work shifts can affect overall wellbeing. Stress due to work is believed to play a crucial role in influencing metabolic problems and could affect glycemic control [55]. Chronic exposure to stressors over-activates the hypothalamic-pituitary-adrenal (HPA) axis and increases counter regulatory hormone response, increasing the risk of T2DM [56]. Recognition of psychosocial factors and stress management intervention programs should be part of a comprehensive approach to T2DM.

General psychological distress, including isolation-induced depression, is common in elderly patients with diabetes and is strongly associated with nonadherence to diabetes self-care. Patients with increased levels of depression often present with social withdrawal, disruption from important activities and treatment nonadherence, leading to worse diabetes clinical outcomes. Current research suggests that the relationship between depression and diabetes is bidirectional, so that the risk of developing depressive symptoms is increased in people with diabetes and people with depression also have an increased risk of developing diabetes, suggesting that the treatment of both illnesses should be undertaken to decrease suffering and additional complications [57-60].

\section{Pharmacologic Therapy}

Lifestyle changes may be insufficient to achieve adequate glycemic control, therefore pharmacological therapy should be started.

\subsection{Metformin}

The biguanide metformin is indicated as first-line therapy for the treatment of type 2 diabetes at any age. It acts by inhibiting gluconeogenesis in the liver and increasing peripheral insulin sensitivity. Compared with sulfonylureas, metformin is effective and safer, presenting a reduced risk of adverse events such as hypoglycemia. Nevertheless, its use has been discouraged in patients with chronic kidney disease, hepatic impairment and congestive heart failure due to increased risk for lactic acidosis, though this is a rare condition $[11,17,61,62]$. Metformin may be safely used in patients with preserved renal function (1000 mg/day the maximal suggested dose) but is contraindicated in case of estimated glomerular filtration rate (eGFR) less than $30 \mathrm{~mL} / \mathrm{min}$. In addition, it can be initiated when eGFR is $45-60 \mathrm{~mL} / \mathrm{min}$ and can be continued when eGFR is $30-45 \mathrm{~mL} / \mathrm{min}$, although with a maximal suggested dose of $1000 \mathrm{mg} /$ day [17,61]. Metformin may be 
temporarily discontinued before procedures, during hospitalizations, and when acute illness may compromise renal or liver function.

Adverse effects are common and mainly involve the gastrointestinal tract with bloating, abdominal discomfort and diarrhea, which could be mitigated by gradual dose titration. Additionally, metformin can cause appetite reduction, determining involuntary weight loss, which clearly represents a benefit for individuals with metabolic syndrome, obesity and insulin resistance, but could also be problematic for some older adults. Although metformin seems to be a safe agent with regard to the risk of unintentional weight loss in the population aged 60 years and older, it could affect nutritional status, especially in patients with malnutrition and/or frailty [63,64].

Reduction or elimination of metformin may be necessary for patients experiencing persistent gastrointestinal side effects. The use of metformin has also been associated with vitamin B12 deficiency, so periodic testing of vitamin B12 levels should be performed especially in older people on long-term metformin therapy [64-67].

As a matter of fact, metformin, either in monotherapy or in combination with other glucose-lowering medications, is generally well tolerated, and the improved glycemic control seems to be associated with decreased total serum cholesterol and serum LDL cholesterol, cardiovascular benefits and lower risk for all-cause mortality in elderly diabetic populations $[68,69]$. Moreover, metformin has lower cardiovascular risk, compared to sulfonylurea [70].

\subsection{Insulin Secretagogues: Sulfonylureas and Glitinides}

Sulfonylureas (SUs) and glitinides are the oldest class of oral antihyperglycemic drugs, still commonly used in clinical practice. They work by increasing insulin secretion in pancreatic $\beta$-cells, binding ATP-sensitive Potassium (KATP) channels of plasma membranes.

SUs and other insulin secretagogues are associated with high rates of hypoglycemia and major weight gain, thus they should possibly be avoided and used with caution in geriatric populations. Short-acting SUs such as gliclazide should be preferred as safer option, especially in patients with renal impairment, while long-acting sulfonylureas should definitely be avoided in older people, due to their higher risk of hypoglycemia $[17,71-73]$.

\subsection{Thiazolidinediones}

Thiazolidinediones (TZDs), such as rosiglitazone and pioglitazone, are an oral insulinsensitizing glucose-lowering medication, acting as agonists of the peroxisome proliferatoractivated receptor $\gamma(\operatorname{PPAR} \gamma)$.

The most important side effects are weight gain and fluid retention, therefore their use has been widely limited, given the high prevalence and incidence of heart failure and chronic kidney disease in patients with diabetes mellitus [11,17,61].

Thiazolidinediones have also been associated with loss of bone mineral density (BMD) and increased risk of non-osteoporotic bone fractures, thus further limiting their use in the older populations [74]. These drugs, indeed, activate mesenchymal stem cells and promote preferential differentiation into adipocytes in the bone marrow, reducing differentiation rate of osteoblast precursors cells [75]. Thus, if used at all, thiazolidinediones should be used very cautiously in those patients with or at risk for congestive heart failure, osteoporosis and/or falls or fractures.

\subsection{Incretin-Based Therapies}

Incretins are a group of hormones released by gut after nutrient ingestion that promote glucose-dependent insulin secretion, glucagon inhibition, delay in gastric emptying and appetite reduction. Glucagon-like peptide 1 (GLP-1) and glucose-dependent insulinotropic polypeptide (GIP) are the most important incretins and they are rapidly inactivated by dipeptidyl peptidase-4 (DPP-4) [76-78]. Given their biological action, incretins have become an attractive target for the treatment of T2DM and this has led to the development of DPP-4 inhibitors and degradation-resistant GLP-1-receptor (GLP-1R) agonists. 


\subsection{Dipeptidyl Peptidase-4 Inhibitors}

Dipeptidyl peptidase-4 (DPP-4) inhibitors are generally well tolerated in older adults. They can be administered once daily, have few side effects and low risk of hypoglycemia [78-83].

DPP-4 inhibitors have proven to be safe in terms of cardiovascular (CV) events, CV death and all-cause mortality [82-85]. Several concerns have been raised about the increased risk of hospitalization for heart failure (HF); in particular the SAVOR-TIMI 53 [84] trial reported a significant increase in hospitalizations for HF in patients treated with saxagliptin ( 3.5 vs. $2.8 \%$; HR 1.27; $95 \%$ CI 1.07-1.51; $p=0.007$ ). An increased risk was also found with alogliptin in patients with no previous history of HF in a post-hoc analysis of the EXAMINE trial [86] while the TECOS [82], VIVIDD [87] and CARMELINA [88] trials showed no increased risk in patients receiving, respectively, sitagliptin, vildagliptin and linagliptin.

DPP-4 inhibitors have also been associated with higher risk of pancreatitis $[89,90]$ though a recent meta-analysis failed to detect any relation to pancreatitis, even if it cannot be excluded in patients at higher risk (history of pancreatitis, alcohol abuse, hypertriglyceridemia, etc.) [91]. Pharmacovigilance reports suggested an association also with pancreatic cancer [89,90]; nevertheless available data, although insufficient because of limited duration of trials, seem to exclude such relationship [91-93].

DPP-4 inhibitors are able to lower HbA1c levels by $0.5-0.8 \%$ [94-96], therefore monotherapy may be used in patients with $\mathrm{HbA1c}$ value close to the target.

The most widely used dual combination is the one with metformin; however, DPP-4 inhibitors can also be added to metformin and Sodium-glucose Cotransporter-2(SGLT-2) inhibitors or to metformin and insulin. Concomitant use of DPP-4 inhibitors and GLP-1R agonists is not recommended due to scant synergistic effects [97].

\subsection{Glucagon-like Peptide 1 Receptor (GLP-1R) Agonists}

GLP-1R agonists are highly effective, capable of lower $\mathrm{HbA1c}$ by $1-1.8 \%[98,99]$ and well tolerated in older adults without causing hypoglycemia when used in monotherapy [98-104].

Several trials demonstrated cardiovascular benefits. In the Harmony Outcomes study, the addition of albiglutide to standard care versus placebo reduced the risk of major cardiovascular events (MACE) by $22 \%$ [105]. In the LEADER trial, liraglutide reduced the risk of MACE by 13\% [106] and a subsequent post-hoc analysis showed a $34 \%$ risk reduction of MACE in patients 75 years or older [107]. Semaglutide and dulaglutide were also associated with decreased risk of cardiovascular events, as reported in the SUSTAIN6 [108] and REWIND [109] trials. Oral semaglutide had similar results to placebo in terms of CV outcomes [110]; neutral effect on cardiovascular outcomes were also described in the ELIXA trial, investigating the effect of lixisenatide in patients with T2DM and recent acute coronary event (within 180 days) [111]. Similarly, the EXSCEL trial showed that the incidence of MACE did not differ significantly between patients treated with exenatide compared to placebo [112]. However, a recent meta-analysis reported that treatment with GLP-1R agonists reduces MACE by $12 \%$ (HR $0.88,95 \%$ CI $0.82-0.94 ; p<0.0001$ ) [113]. In terms of renal outcomes, this class of drugs have proven to lower kidney events, mainly reducing macroalbuminuria, although there was a nonsignificant effect of GLP1-R agonists on the risk of doubling serum creatinine [114].

While the evidence for this class in older patients continues to grow, there are several practical issues that should be considered. GLP-1R agonists are administered through injection (except for oral semaglutide), therefore older adults with impairment of vision, functional or cognitive status could experience some difficulties; on the other hand, the once-weekly formulation could be a valid option. Moreover, they are related to nausea and weight loss, in particular at the beginning of the treatment, hence are not suitable for frail malnourished patients [17]. 


\subsection{Sodium-Glucose Cotransporter 2 Inhibitors}

Sodium-glucose cotransporter 2 inhibitors (SGLT2-i) represent a novel class of oral anti-diabetic agents, emerging as an important therapeutic option for the management of type 2 diabetes. SGLT-I inhibitors act by inducing glycosuria, and consequently osmotic diuresis, by inhibiting the cotransport of glucose coupled with sodium in the renal proximal tubules; the glucose excreted acts as a non-reabsorbable substance under SGLT2 inhibitors' administration [115]. Due to this mechanism, SGLT2-i lower blood glucose levels independently of insulin, resulting in reduced insulin secretion. A recent review showed that the use of SGLT2-i in type 2 diabetes had major advantages in terms of insulin dose reduction [116].

Nevertheless, the diuretic action induced by SGLT2-i is actually mainly based on secondary inhibition in the loop of Henle. In order to keep the tubular fluid isotonic to blood, water is reabsorbed from the proximal tubules, which are highly permeable to water, while the reabsorption of sodium and chloride proceeds through the proximal tubules with different multiple mechanisms, even after the administration of SGLT2 inhibitors. The proximal tubular fluid is transferred to the loop of Henle with a progressively reduced concentration of sodium and chloride, resulting in a significant inhibition of reabsorption due to a decrease in chloride concentration, probably because chloride plays an essential role in the functioning of sodium-chloride-potassium cotransporters (NKCC) $[117,118]$.

Basically, SGLT2 inhibitors act as loop diuretics reducing body fluid volume, which may partly explain their cardiovascular benefits. In addition to glycemic control, SGLT2-i have been reported to decrease the risk of cardiovascular events and mortality, primarily through reduction of heart failure development or progression $[119,120]$.

SGLT2 inhibitors induce plasma volume contraction without activation of the sympathetic nervous system; moreover, they reduce arterial stiffness and improve endothelial function. Natriuresis and vascular stiffness reduction are probably the most significant mediators responsible for the antihypertensive effects of SGLT2-i. Finally, SGLT-2 inhibitors induce oxidation of $\beta$-hydroxybutyrate, reduce oxygen consumption and increase oxygen delivery, improving the efficiency of myocardial energetics [116,121-123].

Clinically available SGLT2-inhibitors are canagliflozin, dapagliflozin and empagliflozin. New emerging data show they are associated with beneficial effects on cardiovascular events even in older adults $[11,124]$. The EMPA-REG OUTCOME trial reported positive cardiovascular outcomes in patients with diabetes at high risk for cardiovascular events receiving empagliflozin in addition to standard therapy, showing a significant reduction in cardiovascular mortality and hospitalization for heart failure [125-127].

Dapaglifozin appears to reduce the risk of hospitalization for heart failure, cardiovascular death and major adverse cardiovascular events in patients with previous myocardial infarction (MI), as shown in a sub-analysis from the DECLARE-TIMI 58 trial [128,129]. Moreover, dapagliflozin appears to reduce weight, blood pressure and urinary albu$\mathrm{min} /$ creatinine ratio (UACR) in patients with type 2 diabetes, albuminuria and moderate renal impairment [130,131]. In two sister trials involving more than 10,000 patients with type 2 diabetes and established cardiovascular disease or at high cardiovascular risk, i.e., the CANVAS and CANVAS-R trials, canaglifozin treatment was associated with lower rates of death from cardiovascular causes, nonfatal myocardial infarction, and nonfatal stroke, compared to the placebo group, but with an elevated risk of amputation [132-135]. Finally, increased renal protection with reduced kidney function decline was also observed in the CANVAS studies, as also reported with empagliflozin and dapagliflozin [135].

Since SGLT2 inhibitors show excellent results in the treatment of diabetes mellitus while also reducing cardiovascular events and death, overall they represent a promising novel therapeutic option for elderly patients $[11,26,136]$. Indeed, the stratified analyses of the trials of this drug class indicate that older patients have similar or greater benefits than younger patients.

The main adverse effects are generally mild urogenital infection, candidiasis risk and polyuria. In addition, an increased risk of fracture was observed with canagliflozin 
treatment, especially in those with high risk of cardiovascular disease and lower filtration rate, probably due to increased urine calcium excretion [136]. Overall, the safety profile of SGLT2i is good, especially because of its oral route of administration, lower risk of hypoglycemia and good tolerability.

As new evidence on cardiac and renal benefits related to SGLT-2 inhibitors and GLP-1R agonists has started to emerge, guidelines have markedly shifted their recommendations, although side effects such as volume depletion may be more common among older patients. Overall, metformin remains the cornerstone of T2DM treatment and both American Diabetes Association [61] and the European Association for the study of Diabetes (EASD) [136] suggest that the add-on therapy should be based on evaluation of cardiovascular disease, chronic kidney disease and heart failure. For patients with established CV disease, they now advise the use of either a SGLT-2 inhibitor or GLP-1R agonist with proven cardiovascular benefit. For those with HF the early use of a SGLT-2 inhibitor with proven benefit is recommended. Finally, for those with chronic kidney disease, a SGLT-2 inhibitor should be preferred or, if not tolerated or contraindicated, a GLP-1R agonist should be started. Table 2 summarizes oral T2DM treatments, contraindications and possible side effects.

Table 2. Oral antidiabetic agents: contraindications and side effects.

\begin{tabular}{|c|c|c|c|}
\hline Class/Drug & $\begin{array}{c}\text { Risk of } \\
\text { Hypoglycemia }\end{array}$ & Contraindications & $\begin{array}{l}\text { Major Side Effects and } \\
\text { Warnings }\end{array}$ \\
\hline Metformin & no & $\mathrm{eGFR}<30 \mathrm{~mL} / \mathrm{min}$ & $\begin{array}{l}\text { Bloating, abdominal } \\
\text { discomfort, diarrhea, vitamin } \\
\text { B12 deficiency, weight loss }\end{array}$ \\
\hline DPP-4 inhibitors & no & & $\begin{array}{l}\text { Potential risk of pancreatitis, } \\
\text { potential slight increased risk } \\
\text { for heart failure with } \\
\text { saxagliptin and alogliptin }\end{array}$ \\
\hline GLP-1R agonists & no & $\begin{array}{l}\text { Not suitable in frail } \\
\text { malnourished } \\
\text { patients }\end{array}$ & $\begin{array}{l}\text { Potential risk of pancreatitis, } \\
\text { nausea, diarrhea, weight loss }\end{array}$ \\
\hline SGLT2 inhibitors & no & $\begin{array}{l}\text { Less effective with } \\
\text { eGFR }<60 \mathrm{~mL} / \mathrm{min}\end{array}$ & $\begin{array}{l}\text { Genital infections, increased } \\
\text { risk of diabetic ketoacidosis }\end{array}$ \\
\hline $\begin{array}{l}\text { Sulphonyl-ureas } \\
\text { and glinides }\end{array}$ & yes & & $\begin{array}{c}\text { Increased risk of } \\
\text { hypoglycemia, major weight } \\
\text { gain }\end{array}$ \\
\hline Thiazolidinediones & no & $\begin{array}{l}\text { Not suitable in } \\
\text { patients with heart } \\
\text { failure }\end{array}$ & $\begin{array}{l}\text { Weight gain, fluid retention, } \\
\text { loss of bone mineral density, } \\
\text { increased risk of } \\
\text { non-osteoporotic bone } \\
\text { fractures }\end{array}$ \\
\hline
\end{tabular}

Abbreviations. eGFR: estimated glomerular filtration rate. DPP-4: Dipeptidyl peptidase-4. GLP-1: Glucagon-like peptide 1. SGLT2-i: Sodium-glucose Cotransporter-2 inhibitors.

\subsection{Insulin Therapy}

Lifelong insulin treatment remains the cornerstone of management of type 1 diabetes, where slow destruction of pancreatic $\beta$-cell occurs with loss of function and insulin deficiency, providing the best combination of effectiveness and safety. Insulin therapy is usually initiated in older patients with type 2 diabetes, often added on top of oral agents when the glycemic control is not sufficient. On the other hand, a strict glycemic control may increase the risk of adverse events, such as hypoglycemia and falls [137].

The optimal management of diabetes in the elderly is more complicated than in their younger counterparts because of the heterogeneity and the unique characteristics of these patients; thus, a careful consideration of concomitant geriatric syndromes and chronic conditions is needed. Functional status, cognitive decline, comorbid illnesses and patient's setting should be considered while choosing insulin as the most appropriate therapeutic 
regimen for older people with diabetes [61]. Insulin treatment in the elderly has been limited because of the risks associated to its use, including hypoglycemia and risk of falls. For patients with life-limiting comorbid illnesses and limited functional status, multiple daily injection of insulin may be too difficult to manage. Patients and caregivers should be educated to understand insulin injection and to recognize and manage hypoglycemia. Insulin pen devices are recommended for patients with limited manual ability or visual impairment, in order to facilitate insulin dosing, maintain their independence and facilitate patient adherence to therapy $[17,61]$.

Long-acting insulin analogues (insulin detemir and glargine) are associated with minimal side effects and may represent the most reasonable choice for basal insulin therapy in elderly patients. After injecting, they form a slowly absorbed precipitate in the subcutaneous tissue, determining their long half-life. A once-daily approach would provide a modest peak in insulin availability, coinciding with the main meal of the day, minimizing the risk of nocturnal hypoglycemia $[135,138,139]$. Thus, once-daily basal insulin injection therapy may be a reasonable option in many older patients.

\section{Conclusions}

Diabetes is an increasingly prevalent disease among older adults, representing a tough challenge for the physician, due to the high heterogeneity of this population. The onset of diabetes in the older population may be unrecognized, due to nonspecific symptoms and other concomitant chronic diseases, usually characterizing geriatric syndromes. Advanced age, together with malnutrition and/or weight loss, reduced physical activity, isolation, and depression may be responsible for increased rate of complications due to unrecognized hyper or hypoglycemia. Given this, managing diabetes in older age groups remains an important clinical challenge for all physicians, either primary care providers or specialists; considering frailty and/or multiple comorbidities, therapeutic intervention has to be individualized and the patient-centered glycemic target is needed. The targeted approach is necessary to achieve glycemic control, avoiding dangerous hypo- and hyperglycemic events and, therefore, favoring healthy aging. Lifestyle changes, with particular attention to diet and physical activity, must be encouraged as a first therapeutic approach. A comprehensive geriatric assessment should be performed at diagnosis of diabetes to better understand cognitive, visual and motor abilities, and coexisting comorbidities. In the choice of anti-hyperglycemic strategies, drugs with proven tolerability, safety, and minimal hypoglycemic risk should be preferred. Anti-diabetes treatment regimens in the elderly must be simple, sustainable and safe to best mirror patients' preferences, wishes, and needs. In conclusion, a comprehensive geriatric assessment has become crucial for the optimal management of T2DM; more attention should be focused on functional and cognitive status as well as social environment. Screening for traditional diabetes complications and geriatric issues (polypharmacy, falls, delirium, malnutrition, urinary incontinence, etc.) should be regularly performed. Treatment targets need to be outlined based on the kind of drug prescribed and overall function in order to avoid both hypo- and hyperglycemia, to reduce the incidence of complications and to prevent or, at least, delay disability.

Author Contributions: Conceptualization, F.M., A.M.C., V.C. and S.R.; writing-original draft preparation, A.M.C. and S.R.; writing-review and editing, V.C., C.O. and N.C.; supervision, V.C. and F.M. All authors have read and agreed to the published version of the manuscript.

Funding: This research received no external funding.

Institutional Review Board Statement: Not applicable.

Informed Consent Statement: Not applicable.

Data Availability Statement: Not applicable.

Conflicts of Interest: The authors declare no conflict of interest. 


\section{References}

1. Williams, R.; Colagiuri, S.; Almutairi, R.; Montoya, P.A.; Basit, A.; Beran, D.; Besançon, S.; Bommer, C.; Borgnakke, W.; Boyko, E.; et al. IDF Diabetes Atlas, 9th ed.; International Diabetes Federation: Brussels, Belgium, 2019.

2. Corriere, M.; Rooparinesingh, N.; Kalyani, R.R. Epidemiology of Diabetes and Diabetes Complications in the Elderly: An Emerging Public Health Burden. Curr. Diabetes Rep. 2013, 13, 805-813. [CrossRef] [PubMed]

3. Yang, Y.; Hu, X.; Zhang, Q.; Zou, R. Diabetes mellitus and risk of falls in older adults: A systematic review and meta-analysis. Age Ageing 2016, 45, 761-767. [CrossRef] [PubMed]

4. Bai, J.; Gao, Q.; Wang, C.; Dai, J. Diabetes mellitus and risk of low-energy fracture: A meta-analysis. Aging Clin. Exp. Res. 2019, 32, 2173-2186. [CrossRef] [PubMed]

5. Xue, M.; Xu, W.; Ou, Y.-N.; Cao, X.-P.; Tan, M.-S.; Tan, L.; Yu, J.-T. Diabetes mellitus and risks of cognitive impairment and dementia: A systematic review and meta-analysis of 144 prospective studies. Ageing Res. Rev. 2019, 55, 100944. [CrossRef]

6. Van Sloten, T.T.; Sedaghat, S.; Carnethon, M.R.; Launer, L.J.; Stehouwer, C.D. Cerebral microvascular complications of type 2 diabetes: Stroke, cognitive dysfunction, and depression. Lancet Diabetes Endocrinol. 2020, 8, 325-336. [CrossRef]

7. Kim, Y.-G.; Park, D.G.; Moon, S.Y.; Jeon, J.Y.; Kim, H.J.; Kim, D.J.; Lee, K.-W.; Han, S.J. Hypoglycemia and Dementia Risk in Older Patients with Type 2 Diabetes Mellitus: A Propensity-Score Matched Analysis of a Population-Based Cohort Study. Diabetes Metab. J. 2020, 44, 125-133. [CrossRef]

8. Laiteerapong, N.; Huang, E.S. Chapter 16: Diabetes in Older Adults. In Diabetes in America, 3rd ed.; National Institute of Diabetes and Digestive and Kidney Diseases: Bethesda, MD, USA, 2018; pp. 1-26.

9. Sinclair, A.; Dunning, T.; Rodríguez-Mañas, L. Diabetes in older people: New insights and remaining challenges. Lancet Diabetes Endocrinol. 2015, 3, 275-285. [CrossRef]

10. Fortini, A.; Morettini, A.; Tavernese, G.; Facchini, S.; Tofani, L.; Pazzi, M. Delirium in elderly patients hospitalized in internal medicine wards. Intern. Emerg. Med. 2013, 9, 435-441. [CrossRef]

11. Sesti, G.; Incalzi, R.A.; Bonora, E.; Consoli, A.; Giaccari, A.; Maggi, S.; Paolisso, G.; Purrello, F.; Vendemiale, G.; Ferrara, N. Management of diabetes in older adults. Nutr. Metab. Cardiovasc. Dis. 2018, 28, 206-218. [CrossRef]

12. Pories, W.J.; Dohm, G.L. Diabetes: Have We Got It All Wrong?: Hyperinsulinism as the culprit: Surgery provides the evidence. Diabetes Care 2012, 35, 2438-2442. [CrossRef]

13. Janssen, J. Hyperinsulinemia and Its Pivotal Role in Aging, Obesity, Type 2 Diabetes, Cardiovascular Disease and Cancer. Int. J. Mol. Sci. 2021, 22, 7797. [CrossRef]

14. Miller, M.E.; Bonds, D.E.; Gerstein, H.C.; Seaquist, E.R.; Bergenstal, R.M.; Calles-Escandon, J.; Childress, R.D.; Craven, T.E.; Cuddihy, R.M.; Dailey, G.; et al. The effects of baseline characteristics, glycaemia treatment approach, and glycated haemoglobin concentration on the risk of severe hypoglycaemia: Post hoc epidemiological analysis of the ACCORD study. BMJ 2010, 340, b5444. [CrossRef] [PubMed]

15. Patel, A.; MacMahon, S.; Chalmers, J.; Neal, B.; Billot, L.; Joshi, R.; Woodward, M.; Marre, M.; Travert, F.; Cooper, M.; et al. Intensive Blood Glucose Control and Vascular Outcomes in Patients with Type 2 Diabetes. N. Engl. J. Med. 2008, 358, $2560-2572$. [CrossRef]

16. Duckworth, W.; Abraira, C.; Moritz, T.; Reda, D.; Emanuele, N.; Reaven, P.D.; Zieve, F.J.; Marks, J.; Davis, S.N.; Hayward, R.; et al. Glucose Control and Vascular Complications in Veterans with Type 2 Diabetes. N. Engl. J. Med. 2009, 360, 129-139. [CrossRef]

17. American Diabetes Association. 12. Older Adults: Standards of Medical Care in Diabetes-2021. Diabetes Care 2020, 44, S168-S179. [CrossRef]

18. Dunning, T.; Sinclair, A. New IDF Guideline for managing type 2 diabetes in older people. Diabetes Res. Clin. Pract. 2014, 103, 538-540. [CrossRef]

19. American Diabetes Association. 6. Glycemic Targets: Standards of Medical Care in Diabetes-2021. Diabetes Care 2020, 44, S73-S84. [CrossRef]

20. Dungan, K.; Merrill, J.; Long, C.; Binkley, P. Effect of beta blocker use and type on hypoglycemia risk among hospitalized insulin requiring patients. Cardiovasc. Diabetol. 2019, 18, 163. [CrossRef] [PubMed]

21. Cruz, P. Inpatient Hypoglycemia: The Challenge Remains. J. Diabetes Sci. Technol. 2020, 14, 560-566. [CrossRef] [PubMed]

22. Freeman, J. Management of hypoglycemia in older adults with type 2 diabetes. Postgrad. Med. 2019, 131, 241-250. [CrossRef] [PubMed]

23. American Diabetes Association. 5. Facilitating Behavior Change and Well-being to Improve Health Outcomes: Standards of Medical Care in Diabetes-2021. Diabetes Care 2020, 44, S53-S72. [CrossRef]

24. Antonelli-Incalzi, R.; Ferrara, N.; Maggi, S.; Paolisso, G. Personalizzazione del Trattamento dell ‘Iperglicemia Nell’ Anziano con Diabete Tipo 2. 2017. Available online: https:/ /www.sigg.it/wp-content/uploads/2018/06/SID-SIGG-Documento-ufficiale.pdf (accessed on 17 July 2021).

25. World Journal of Diabetes. pp. 230-310. Available online: https://f6publishing.blob.core.windows.net/ccc9e3d1-648d-4b5f-a903 -490a4f45095e/WJD-8-278.pdf (accessed on 17 July 2021).

26. Leroith, D.; Biessels, G.J.; Braithwaite, S.S.; Casanueva, F.F.; Draznin, B.; Halter, J.B.; Hirsch, I.B.; McDonnell, M.; Molitch, M.E.; Murad, M.H.; et al. TReatment of diabetes in older adults: An endocrine society clinical practice guideline. J. Clin. Endocrinol. Metab. 2019, 104, 1520-1574. [CrossRef] [PubMed] 
27. Kolb, H.; Martin, S. Environmental/lifestyle factors in the pathogenesis and prevention of type 2 diabetes. BMC Med. 2017, 15, 131. [CrossRef]

28. Aune, D.; Norat, T.; Romundstad, P.R.; Vatten, L.J. Whole grain and refined grain consumption and the risk of type 2 diabetes: A systematic review and dose-response meta-analysis of cohort studies. Eur. J. Epidemiol. 2013, 28, 845-858. [CrossRef]

29. Trichopoulou, A.; A Martínez-González, M.; Tong, T.Y.; Forouhi, N.G.; Khandelwal, S.; Prabhakaran, D.; Mozaffarian, D.; de Lorgeril, M. Definitions and potential health benefits of the Mediterranean diet: Views from experts around the world. BMC Med. 2014, 12, 112. [CrossRef] [PubMed]

30. Salas-Salvadó, J.; Bulló, M.; Babio, N.; Martínez-González, M.; Ibarrola-Jurado, N.; Basora, J.; Estruch, R.; Covas, M.I.; Corella, D.; Arós, F.; et al. Reduction in the Incidence of Type 2 Diabetes with the Mediterranean Diet: Results of the PREDIMED-Reus nutrition intervention randomized trial. Diabetes Care 2010, 34, 14-19. [CrossRef]

31. Diabetes Prevention Program Research Group. 10-year follow-up of diabetes incidence and weight loss in the Diabetes Prevention Program Outcomes Study. Lancet 2009, 374, 1677-1686. [CrossRef]

32. Morante, J.J.H.; Martínez, C.G.; Morillas-Ruiz, J.M. Dietary Factors Associated with Frailty in Old Adults: A Review of Nutritional Interventions to Prevent Frailty Development. Nutrients 2019, 11, 102. [CrossRef]

33. Kelly, T.; Unwin, D.; Finucane, F. Low-Carbohydrate Diets in the Management of Obesity and Type 2 Diabetes: A Review from Clinicians Using the Approach in Practice. Int. J. Environ. Res. Public Health 2020, 17, 2557. [CrossRef]

34. Saslow, L.R.; Summers, C.; Aikens, E.J.; Unwin, D.J. Outcomes of a Digitally Delivered Low-Carbohydrate Type 2 Diabetes Self-Management Program: 1-Year Results of a Single-Arm Longitudinal Study. JMIR Diabetes 2018, 3, e12. [CrossRef]

35. Leslie, W.S.; Ford, I.; Sattar, N.; Hollingsworth, K.G.; Adamson, A.; Sniehotta, F.F.; McCombie, L.; Brosnahan, N.; Ross, H.; Mathers, J.C.; et al. The Diabetes Remission Clinical Trial (DiRECT): Protocol for a cluster randomised trial. BMC Fam. Pract. 2016, 17, 20. [CrossRef] [PubMed]

36. Lean, M.E.; Leslie, W.S.; Barnes, A.C.; Brosnahan, N.; Thom, G.; McCombie, L.; Peters, C.; Zhyzhneuskaya, S.; Al-Mrabeh, A.; Hollingsworth, K.G.; et al. Primary care-led weight management for remission of type 2 diabetes (DiRECT): An open-label, cluster-randomised trial. Lancet 2018, 391, 541-551. [CrossRef]

37. Hallberg, S.J.; Gershuni, V.M.; Hazbun, T.L.; Athinarayanan, S.J. Reversing Type 2 Diabetes: A Narrative Review of the Evidence. Nutrients 2019, 11, 766. [CrossRef]

38. Hallberg, S.J.; McKenzie, A.L.; Williams, P.T.; Bhanpuri, N.H.; Peters, A.L.; Campbell, W.W.; Hazbun, T.L.; Volk, B.M.; McCarter, J.; Phinney, S.D.; et al. Effectiveness and Safety of a Novel Care Model for the Management of Type 2 Diabetes at 1 Year: An Open-Label, Non-Randomized, Controlled Study. Diabetes Ther. 2018, 9, 583-612. [CrossRef] [PubMed]

39. Caprio, M.; The Cardiovascular Endocrinology Club of the Italian Society of Endocrinology; Infante, M.; Moriconi, E.; Armani, A.; Fabbri, A.; Mantovani, G.; Mariani, S.; Lubrano, C.; Poggiogalle, E.; et al. Very-low-calorie ketogenic diet (VLCKD) in the management of metabolic diseases: Systematic review and consensus statement from the Italian Society of Endocrinology (SIE). J. Endocrinol. Investig. 2019, 42, 1365-1386. [CrossRef] [PubMed]

40. Volkert, D.; Beck, A.M.; Cederholm, T.; Cruz-Jentoft, A.J.; Goisser, S.; Hooper, L.; Kiesswetter, E.; Maggio, M.; Raynaud-Simon, A.; Sieber, C.C.; et al. ESPEN guideline on clinical nutrition and hydration in geriatrics. Clin. Nutr. 2018, 38, 10-47. [CrossRef] [PubMed]

41. Omura, T.; Tamura, Y.; Yamaoka, T.; Yoshimura, Y.; Sakurai, T.; Umegaki, H.; Kamada, C.; Iimuro, S.; Ohashi, Y.; Ito, H.; et al. Assessing the association between optimal energy intake and all-cause mortality in older patients with diabetes mellitus using the Japanese Elderly Diabetes Intervention Trial. Geriatr. Gerontol. Int. 2019, 20, 59-65. [CrossRef]

42. Rahi, B.; Morais, J.A.; Gaudreau, P.; Payette, H.; Shatenstein, B. Energy and protein intakes and their association with a decline in functional capacity among diabetic older adults from the NuAge cohort. Eur. J. Nutr. 2015, 55, 1729-1739. [CrossRef]

43. Pflipsen, M.C.; Oh, R.C.; Saguil, A.; Seehusen, D.; Seaquist, D.; Topolski, R. The Prevalence of Vitamin B12 Deficiency in Patients with Type 2 Diabetes: A Cross-Sectional Study. J. Am. Board Fam. Med. 2009, 22, 528-534. [CrossRef]

44. Kibirige, D.; Mwebaze, R. Vitamin B12 deficiency among patients with diabetes mellitus: Is routine screening and supplementation justified? J. Diabetes Metab. Disord. 2013, 12, 17. [CrossRef]

45. Gschwind, Y.J.; Kressig, R.W.; Lacroix, A.; Muehlbauer, T.; Pfenninger, B.; Granacher, U. A best practice fall prevention exercise program to improve balance, strength/power, and psychosocial health in older adults: Study protocol for a randomized controlled trial. BMC Geriatr. 2013, 13, 105. [CrossRef]

46. Natovich, R.; Gayus, N.; Azmon, M.; Michal, H.; Twito, O.G.; Yair, T.; Raudoi, S.; Kapra, O.; Cukierman-Yaffe, T. A Comprehensive Intervention for Promoting Successful Aging amongst Older People With Diabetes With Below-Normal Cognitive Function-A Feasibility Study. Front. Endocrinol. 2020, 11, 348. [CrossRef] [PubMed]

47. Bernard, M.; Müller, N.; Hecht, L.; Fabisch, G.; Harder, A.; Luck-Sikorski, C. Efficacy of DiaLife, an education program for relatives of adult patients with diabetes-study protocol of a cluster randomized controlled trial. Trials 2019, 20, 523. [CrossRef] [PubMed]

48. Davies, M.; Heller, S.; Skinner, T.; Campbell, M.J.; Carey, E.M.; Cradock, S.; Dallosso, H.M.; Daly, H.; Doherty, Y.; Eaton, S.; et al. Effectiveness of the diabetes education and self management for ongoing and newly diagnosed (DESMOND) programme for people with newly diagnosed type 2 diabetes: Cluster randomised controlled trial. BMJ 2008, 336, 491-495. [CrossRef] 
49. Brady, E.M.; Bamuya, C.; Beran, D.; Correia, J.; Crampin, A.; Damasceno, A.; Davies, M.J.; Hadjiconstantinou, M.; Harrington, D.; Khunti, K.; et al. EXTending availability of self-management structured EducatioN programmes for people with type 2 Diabetes in low-to-middle income countries (EXTEND)_A feasibility study in Mozambique and Malawi. BMJ Open 2021, 11, e047425. [CrossRef]

50. Lee, S.W.H.; Ng, K.Y.; Chin, W.K. The impact of sleep amount and sleep quality on glycemic control in type 2 diabetes: A systematic review and meta-analysis. Sleep Med. Rev. 2016, 31, 91-101. [CrossRef] [PubMed]

51. Reutrakul, S.; Van Cauter, E. Sleep influences on obesity, insulin resistance, and risk of type 2 diabetes. Metabolism 2018, 84, 56-66. [CrossRef]

52. Shan, Z.; Majewski, C.; Xie, M.; Yan, P.; Guo, Y.; Bao, W.; Rong, Y.; Jackson, C.L.; Hu, F.B.; Liu, L. Sleep Duration and Risk of Type 2 Diabetes: A Meta-analysis of Prospective Studies. Diabetes Care 2015, 38, 529-537. [CrossRef]

53. Larcher, S.; Benhamou, P.-Y.; Pépin, J.-L.; Borel, A.-L. Sleep habits and diabetes. Diabetes Metab. 2015, 41, 263-271. [CrossRef]

54. Ogilvie, R.P.; Patel, S.R. The Epidemiology of Sleep and Diabetes. Curr. Diabetes Rep. 2018, 18, 82. [CrossRef]

55. Mishra, A.; Podder, V.; Modgil, S.; Khosla, R.; Anand, A.; Nagarathna, R.; Malhotra, R.; Nagendra, H.R. Higher Perceived Stress and Poor Glycemic Changes in Prediabetics and Diabetics Among Indian Population. J. Med. Life 2020, 13, $132-137$.

56. Kelly, S.J.; Ismail, M. Stress and Type 2 Diabetes: A Review of How Stress Contributes to the Development of Type 2 Diabetes. Annu. Rev. Public Health 2015, 36, 441-462. [CrossRef]

57. Gonzalez, J.S.; Peyrot, M.; McCarl, L.A.; Collins, E.M.; Serpa, L.; Mimiaga, M.J.; Safren, S.A. Depression and Diabetes Treatment Nonadherence: A Meta-Analysis. Diabetes Care 2008, 31, 2398-2403. [CrossRef] [PubMed]

58. Roy, T.; Lloyd, C.E. Epidemiology of depression and diabetes: A systematic review. J. Affect. Disord. 2012, 142, S8-S21. [CrossRef]

59. Wang, L.; Li, J.; Dang, Y.; Ma, H.; Niu, Y. Relationship between Social Capital and Depressive Symptoms Among Type 2 Diabetes Mellitus Patients in Northwest China: A Mediating Role of Sleep Quality. Front. Psychiatry 2021, 12, 725197. [CrossRef] [PubMed]

60. Hoogendoorn, C.J.; Schechter, C.B.; Llabre, M.M.; Walker, A.E.; Gonzalez, J.S. Distress and Type 2 Diabetes Self-Care: Putting the Pieces Together. Ann. Behav. Med. 2021, 55, 938-948. [CrossRef] [PubMed]

61. American Diabetes Association. 9. Pharmacologic Approaches to Glycemic Treatment: Standards of Medical Care in Diabetes2021. Diabetes Care 2020, 44, S111-S124. [CrossRef]

62. DeFronzo, R.; Fleming, G.A.; Chen, K.; Bicsak, T.A. Metformin-associated lactic acidosis: Current perspectives on causes and risk. Metabolism 2016, 65, 20-29. [CrossRef]

63. Bahat, G.; Catikkas, N.M.; Karan, M.A.; Petrovic, M. Management of type 2 diabetes mellitus in older adults: Eight case studies with focus SGLT-2 inhibitors and metformin. Acta Clin. Belg. 2021, 1-8. [CrossRef]

64. Solymár, M.; Ivic, I.; Pótó, L.; Hegyi, P.; Garami, A.; Hartmann, P.; Pétervári, E.; Czopf, L.; Hussain, A.; Gyöngyi, Z.; et al. Metformin induces significant reduction of body weight, total cholesterol and LDL levels in the elderly-A meta-analysis. PLoS ONE 2018, 13, e0207947. [CrossRef]

65. Flory, J.; Lipska, K. Metformin in 2019. JAMA 2019, 321, 1926-1927. [CrossRef] [PubMed]

66. Schlender, L.; Martinez, Y.V.; Adeniji, C.; Reeves, D.; Faller, B.; Sommerauer, C.; Al Qur'An, T.; Woodham, A.; Kunnamo, I.; Sönnichsen, A.; et al. Efficacy and safety of metformin in the management of type 2 diabetes mellitus in older adults: A systematic review for the development of recommendations to reduce potentially inappropriate prescribing. BMC Geriatr. 2017, 17, 227. [CrossRef] [PubMed]

67. Schernthaner, G.; Schernthaner, G.-H. The right place for metformin today. Diabetes Res. Clin. Pr. 2019, 159, 107946. [CrossRef]

68. Sanchez-Rangel, E.; Inzucchi, S.E. Metformin: Clinical use in type 2 diabetes. Diabetologia 2017, 60, 1586-1593. [CrossRef] [PubMed]

69. Roumie, C.L.; Min, J.Y.; McGowan, L.D.; Presley, C.; Grijalva, C.; Hackstadt, A.J.; Hung, A.M.; Greevy, R.A.; Elasy, T.; Griffin, M.R. Comparative Safety of Sulfonylurea and Metformin Monotherapy on the Risk of Heart Failure: A Cohort Study. J. Am. Hear. Assoc. 2017, 6, e005379. [CrossRef] [PubMed]

70. 2019 American Geriatrics Society Beers Criteria ${ }^{\circledR} U$ pdate Expert Panel. American Geriatrics Society 2019 Updated AGS Beers Criteria ${ }^{\circledR}$ for Potentially Inappropriate Medication Use in Older Adults. J. Am. Geriatr. Soc. 2019, 67, 674-694. [CrossRef]

71. Webb, D.R.; Davies, M.J.; Jarvis, J.; Seidu, S.; Khunti, K. The right place for Sulphonylureas today: Part of 'Review the Series: Implications of recent CVOTs in Type 2 diabetes mellitus'. Diabetes Res. Clin. Pract. 2019, 157, 107836. [CrossRef]

72. Huang, C.-H.; Umegaki, H.; Watanabe, Y.; Kamitani, H.; Asai, A.; Kanda, S.; Nomura, H.; Kuzuya, M. Potentially inappropriate medications according to STOPP-J criteria and risks of hospitalization and mortality in elderly patients receiving home-based medical services. PLoS ONE 2019, 14, e0211947. [CrossRef]

73. Arnold, S.V.; Inzucchi, S.E.; Echouffo-Tcheugui, J.B.; Tang, F.; Lam, C.S.; Sperling, L.S.; Kosiborod, M. Understanding Contemporary Use of Thiazolidinediones. Circ. Heart Fail. 2019, 12, e005855. [CrossRef]

74. McDonough, A.K.; Rosenthal, R.S.; Cao, X.; Saag, K.G. The effect of thiazolidinediones on BMD and osteoporosis. Nat. Clin. Pr. Endocrinol. Metab. 2008, 4, 507-513. [CrossRef] [PubMed]

75. Campbell, J.E.; Drucker, D.J. Pharmacology, Physiology, and Mechanisms of Incretin Hormone Action. Cell Metab. 2013, 17, 819-837. [CrossRef] [PubMed]

76. Nauck, M.A.; Meier, J.J. Incretin hormones: Their role in health and disease. Diabetes, Obes. Metab. 2018,20 (Suppl. 1), 5-21. [CrossRef] [PubMed] 
77. Schott, G.; Martinez, Y.V.; De Silva, R.E.E.; Renom-Guiteras, A.; Vögele, A.; Reeves, D.; Kunnamo, I.; Marttila-Vaara, M.; Sönnichsen, A. Effectiveness and safety of dipeptidyl peptidase 4 inhibitors in the management of type 2 diabetes in older adults: A systematic review and development of recommendations to reduce inappropriate prescribing. BMC Geriatr. 2017, 17, 226. [CrossRef] [PubMed]

78. Pratley, R.E.; Rosenstock, J.; Pi-Sunyer, F.X.; Banerji, M.A.; Schweizer, A.; Couturier, A.; Dejager, S. Msc Management of Type 2 Diabetes in Treatment-Naive Elderly Patients: Benefits and risks of vildagliptin monotherapy. Diabetes Care 2007, 30, $3017-3022$. [CrossRef] [PubMed]

79. Stafford, S.; Elahi, D.; Meneilly, G.S. Effect of the dipeptidyl peptidase-4 inhibitor sitagliptin in older adults with type 2 diabetes mellitus. J. Am. Geriatr. Soc. 2011, 59, 1148-1149. [CrossRef]

80. Umezawa, S.; Kubota, A.; Maeda, H.; Kanamori, A.; Matoba, K.; Jin, Y.; Minagawa, F.; Obana, M.; Iemitsu, K.; Ito, S.; et al. Two-year assessment of the efficacy and safety of sitagliptin in elderly patients with type 2 diabetes: Post hoc analysis of the ASSET-K study. BMC Endocr. Disord. 2015, 15, 34. [CrossRef]

81. Bethel, M.A.; Engel, S.S.; Green, J.B.; Huang, Z.; Josse, R.G.; Kaufman, K.D.; Standl, E.; Suryawanshi, S.; Van de Werf, F.; McGuire, D.K.; et al. Assessing the Safety of Sitagliptin in Older Participants in the Trial Evaluating Cardiovascular Outcomes with Sitagliptin (TECOS). Diabetes Care 2017, 40, 494-501. [CrossRef]

82. Leiter, L.A.; Teoh, H.; Braunwald, E.; Mosenzon, O.; Cahn, A.; Kumar, K.P.; Smahelova, A.; Hirshberg, B.; Stahre, C.; Frederich, R.; et al. Efficacy and Safety of Saxagliptin in Older Participants in the SAVOR-TIMI 53 Trial. Diabetes Care 2015, 38, 1145-1153. [CrossRef]

83. White, W.B.; Cannon, C.P.; Heller, S.; Nissen, S.E.; Bergenstal, R.M.; Bakris, G.L.; Perez, A.T.; Fleck, P.R.; Mehta, C.R.; Kupfer, S.; et al. Alogliptin after Acute Coronary Syndrome in Patients with Type 2 Diabetes. N. Engl. J. Med. 2013, 369, 1327-1335. [CrossRef]

84. Rosenstock, J.; Perkovic, V.; Johansen, O.E.; Cooper, M.E.; Kahn, S.E.; Marx, N.; Alexander, J.H.; Pencina, M.; Toto, R.D.; Wanner, C.; et al. Effect of Linagliptin vs Placebo on Major Cardiovascular Events in Adults with Type 2 Diabetes and High Cardiovascular and Renal Risk: The CARMELINA Randomized Clinical Trial. JAMA 2019, 321, 69-79. [CrossRef]

85. Zannad, F.; Cannon, C.P.; Cushman, W.C.; Bakris, G.L.; Menon, V.; Perez, A.T.; Fleck, P.R.; Mehta, C.R.; Kupfer, S.; Wilson, C.; et al. Heart failure and mortality outcomes in patients with type 2 diabetes taking alogliptin versus placebo in EXAMINE: A multicentre, randomised, double-blind trial. Lancet 2015, 385, 2067-2076. [CrossRef]

86. McMurray, J.J.; Ponikowski, P.; Bolli, G.B.; Lukashevich, V.; Kozlovski, P.; Kothny, W.; Lewsey, J.D.; Krum, H. Effects of Vildagliptin on Ventricular Function in Patients with Type 2 Diabetes Mellitus and Heart Failure. JACC: Heart Fail. 2017, 6, 8-17. [CrossRef] [PubMed]

87. McGuire, D.K.; Alexander, J.H.; Johansen, O.E.; Perkovic, V.; Rosenstock, J.; Cooper, M.E.; Wanner, C.; Kahn, S.E.; Toto, R.D.; Zinman, B.; et al. Linagliptin Effects on Heart Failure and Related Outcomes in Individuals With Type 2 Diabetes Mellitus at High Cardiovascular and Renal Risk in CARMELINA. Circulation 2019, 139, 351-361. [CrossRef]

88. Faillie, J.-L.; Azoulay, L.; Patenaude, V.; Hillaire-Buys, D.; Suissa, S. Incretin based drugs and risk of acute pancreatitis in patients with type 2 diabetes: Cohort study. BMJ 2014, 348, g2780. [CrossRef] [PubMed]

89. Elashoff, M.; Matveyenko, A.V.; Gier, B.; Elashoff, R.; Butler, P.C. Pancreatitis, Pancreatic, and Thyroid Cancer With Glucagon-Like Peptide-1-Based Therapies. Gastroenterology 2011, 141, 150-156. [CrossRef]

90. Dicembrini, I.; Montereggi, C.; Nreu, B.; Mannucci, E.; Monami, M. Pancreatitis and pancreatic cancer in patientes treated with Dipeptidyl Peptidase-4 inhibitors: An extensive and updated meta-analysis of randomized controlled trials. Diabetes Res. Clin. Pr. 2019, 159, 107981. [CrossRef]

91. Pinto, L.C.; Rados, D.; Barkan, S.S.; Leitao, C.; Gross, J.L. Dipeptidyl peptidase-4 inhibitors, pancreatic cancer and acute pancreatitis: A meta-analysis with trial sequential analysis. Sci. Rep. 2018, 8, 782. [CrossRef]

92. Monami, M.; Dicembrini, I.; Martelli, D.; Mannucci, E. Safety of dipeptidyl peptidase-4 inhibitors: A meta-analysis of randomized clinical trials. Curr. Med. Res. Opin. 2011, 27, 57-64. [CrossRef]

93. Sesti, G.; Avogaro, A.; Belcastro, S.; Bonora, B.M.; Croci, M.; Daniele, G.; Dauriz, M.; Dotta, F.; Formichi, C.; Frontoni, S.; et al. Ten years of experience with DPP-4 inhibitors for the treatment of type 2 diabetes mellitus. Acta Diabetol. 2019, 56, 605-617. [CrossRef]

94. Deacon, C.F.; Holst, J.J. Dipeptidyl peptidase-4 inhibitors for the treatment of type 2 diabetes: Comparison, efficacy and safety. Expert Opin. Pharmacother. 2013, 14, 2047-2058. [CrossRef]

95. Fonseca, V.; Baron, M.; Shao, Q.; Dejager, S. Sustained Efficacy and Reduced Hypoglycemia during One Year of Treatment with Vildagliptin Added to Insulin in Patients with Type 2 Diabetes Mellitus. Horm. Metab. Res. 2008, 40, 427-430. [CrossRef] [PubMed]

96. Gallwitz, B. Clinical Use of DPP-4 Inhibitors. Front. Endocrinol. 2019, 10, 389. [CrossRef] [PubMed]

97. Sposito, A.C.; Berwanger, O.; De Carvalho, L.S.F.; Saraiva, J.F.K. GLP-1RAs in type 2 diabetes: Mechanisms that underlie cardiovascular effects and overview of cardiovascular outcome data. Cardiovasc. Diabetol. 2018, 17, 157. [CrossRef]

98. Meneilly, G.S.; Roy-Duval, C.; Alawi, H.; Dailey, G.; Bellido, D.; Trescoli, C.; Hurtado, H.M.; Guo, H.; Pilorget, V.; Perfetti, R.; et al. Lixisenatide Therapy in Older Patients with Type 2 Diabetes Inadequately Controlled on Their Current Antidiabetic Treatment: The GetGoal-O Randomized Trial. Diabetes Care 2017, 40, 485-493. [CrossRef]

99. Boustani, M.A.; Pittman, I.; Yu, M.; Thieu, V.T.; Varnado, O.J.; Juneja, R. Similar efficacy and safety of once-weekly dulaglutide in patients with type 2 diabetes aged $\geq 65$ and $<65$ years. Diabetes Obes. Metab. 2016, 18, 820-828. [CrossRef] [PubMed] 
100. Raccah, D.; Miossec, P.; Esposito, V.; Niemoeller, E.; Cho, M.; Gerich, J. Efficacy and safety of lixisenatide in elderly ( $\geq 65$ years old) and very elderly ( $\geq 75$ years old) patients with type 2 diabetes: An analysis from the GetGoal phase III programme. Diabetes/Metab. Res. Rev. 2014, 31, 204-211. [CrossRef]

101. Hanefeld, M.; Berria, R.; Lin, J.; Aronson, R.; Darmon, P.; Evans, M.; Van Gaal, L. Lixisenatide Treatment for Older Patients with Type 2 Diabetes Mellitus Uncontrolled on Oral Antidiabetics: Meta-Analysis of Five Randomized Controlled Trials. Adv. Ther. 2014, 31, 861-872. [CrossRef]

102. Pencek, R.; Blickensderfer, A.; Li, Y.; Brunell, S.C.; Chen, S. Exenatide once weekly for the treatment of type 2 diabetes: Effectiveness and tolerability in patient subpopulations. Int. J. Clin. Pract. 2012, 66, 1021-1032. [CrossRef] [PubMed]

103. Bode, B.W.; Brett, J.; Falahati, A.; Pratley, R.E. Comparison of the Efficacy and Tolerability Profile of Liraglutide, a Once-Daily Human GLP-1 Analog, in Patients With Type 2 Diabetes $\geq 65$ and $<65$ Years of Age: A Pooled Analysis from Phase III Studies. Am. J. Geriatr. Pharmacother. 2011, 9, 423-433. [CrossRef]

104. Hernandez, A.F.; Green, J.B.; Janmohamed, S.; D’Agostino, R.B.; Granger, C.B.; Jones, N.P.; Leiter, A.L.; Rosenberg, E.A.; Sigmon, K.N.; Somerville, M.C.; et al. Albiglutide and cardiovascular outcomes in patients with type 2 diabetes and cardiovascular disease (Harmony Outcomes): A double-blind, randomised placebo-controlled trial. Lancet 2018, 392, 1519-1529. [CrossRef]

105. Marso, S.P.; Daniels, G.H.; Brown-Frandsen, K.; Kristensen, P.; Mann, J.F.; Nauck, M.A.; Nissen, S.E.; Pocock, S.; Poulter, N.R.; Ravn, L.S.; et al. Liraglutide and Cardiovascular Outcomes in Type 2 Diabetes. N. Engl. J. Med. 2016, 375, 311-322. [CrossRef] [PubMed]

106. Gilbert, M.P.; Bain, S.C.; Franek, E.; Jodar-Gimeno, E.; Nauck, M.A.; Pratley, R.; Réa, R.R.; Saraiva, J.F.K.; Rasmussen, S.; Tornøe, K.; et al. Effect of Liraglutide on Cardiovascular Outcomes in Elderly Patients: A Post Hoc Analysis of a Randomized Controlled Trial. Ann. Intern. Med. 2018, 170, 423-426. [CrossRef]

107. Marso, S.P.; Bain, S.C.; Consoli, A.; Eliaschewitz, F.G.; Jódar, E.; Leiter, L.A.; Lingvay, I.; Rosenstock, J.; Seufert, J.; Warren, M.L.; et al. Semaglutide and Cardiovascular Outcomes in Patients with Type 2 Diabetes. N. Engl. J. Med. 2016, 375, 1834-1844. [CrossRef] [PubMed]

108. Gerstein, H.C.; Colhoun, H.M.; Dagenais, G.R.; Diaz, R.; Lakshmanan, M.; Pais, P.; Probstfield, J.; Riesmeyer, J.S.; Riddle, M.C.; Rydén, L.; et al. Dulaglutide and cardiovascular outcomes in type 2 diabetes (REWIND): A double-blind, randomised placebocontrolled trial. Lancet 2019, 394, 121-130. [CrossRef]

109. Husain, M.; Birkenfeld, A.L.; Donsmark, M.; Dungan, K.; Eliaschewitz, F.G.; Franco, D.R.; Jeppesen, O.K.; Lingvay, I.; Mosenzon, O.; Pedersen, S.D.; et al. Oral Semaglutide and Cardiovascular Outcomes in Patients with Type 2 Diabetes. N. Engl. J. Med. 2019, 381, 841-851. [CrossRef] [PubMed]

110. Pfeffer, M.A.; Claggett, B.; Diaz, R.; Dickstein, K.; Gerstein, H.; Køber, L.V.; Lawson, F.C.; Ping, L.; Wei, X.; Lewis, E.F.; et al. Lixisenatide in Patients with Type 2 Diabetes and Acute Coronary Syndrome. N. Engl. J. Med. 2015, 373, 2247-2257. [CrossRef] [PubMed]

111. Holman, R.R.; Bethel, M.A.; Mentz, R.J.; Thompson, V.P.; Lokhnygina, Y.; Buse, J.; Chan, J.; Choi, J.; Gustavson, S.M.; Iqbal, N.; et al. Effects of Once-Weekly Exenatide on Cardiovascular Outcomes in Type 2 Diabetes. N. Engl. J. Med. 2017, 377, 1228-1239. [CrossRef] [PubMed]

112. Kristensen, S.L.; Rørth, R.; Jhund, P.S.; Docherty, K.F.; Sattar, N.; Preiss, D.; Køber, L.; Petrie, M.C.; McMurray, J.J.V. Cardiovascular, mortality, and kidney outcomes with GLP-1 receptor agonists in patients with type 2 diabetes: A systematic review and meta-analysis of cardiovascular outcome trials. Lancet Diabetes Endocrinol. 2019, 7, 776-785. [CrossRef]

113. Zelniker, T.A.; Wiviott, S.D.; Raz, I.; Im, K.; Goodrich, E.; Furtado, R.H.M.; Bonaca, M.P.; Mosenzon, O.; Kato, E.; Cahn, A.; et al. Comparison of the Effects of Glucagon-Like Peptide Receptor Agonists and Sodium-Glucose Cotransporter 2 Inhibitors for Prevention of Major Adverse Cardiovascular and Renal Outcomes in Type 2 Diabetes Mellitus. Circulation 2019, 139, $2022-2031$. [CrossRef]

114. Kimura, G. Diuretic Action of Sodium-Glucose Cotransporter 2 Inhibitors and Its Importance in the Management of Heart Failure. Circ. J. 2016, 80, 2277-2281. [CrossRef] [PubMed]

115. John, M.; Gopinath, D.; Jagesh, R. Sodium-glucose cotransporter 2 inhibitors with insulin in type 2 diabetes: Clinical perspectives. Indian J. Endocrinol. Metab. 2016, 20, 22-31. [CrossRef]

116. Kimura, G. Importance of inhibiting sodium-glucose cotransporter and its compelling indication in type 2 diabetes: Pathophysiological hypothesis. J. Am. Soc. Hypertens. 2016, 10, 271-278. [CrossRef]

117. Masuda, T.; Muto, S.; Fukuda, K.; Watanabe, M.; Ohara, K.; Koepsell, H.; Vallon, V.; Nagata, D. Osmotic diuresis by SGLT2 inhibition stimulates vasopressin-induced water reabsorption to maintain body fluid volume. Physiol. Rep. 2020, 8, e14360. [CrossRef]

118. Pradhan, A.; Vohra, S.; Vishwakarma, P.; Sethi, R. Review on sodium-glucose cotransporter 2 inhibitor (SGLT2i) in diabetes mellitus and heart failure. J. Fam. Med. Prim. Care 2019, 8, 1855-1862. [CrossRef] [PubMed]

119. Packer, M.; Anker, S.D.; Butler, J.; Filippatos, G.; Zannad, F. Effects of Sodium-Glucose Cotransporter 2 Inhibitors for the Treatment of Patients With Heart Failure. JAMA Cardiol. 2017, 2, 1025-1029. [CrossRef]

120. Kumar, K.; Behl, T.; Kumar, A.; Arora, S. SGLT-2 Inhibitors: Ideal Remedy for Cardioprotection in Diabetes Mellitus. Curr. Mol. Pharmacol. 2021, 14, 487-497. [CrossRef] [PubMed]

121. Heerspink, H.J.L.; Perkins, B.A.; Fitchett, D.H.; Husain, M.; Cherney, D.Z.I. Sodium Glucose Cotransporter 2 Inhibitors in the Treatment of Diabetes Mellitus. Circulation 2016, 134, 752-772. [CrossRef] 
122. Martens, P.; Mathieu, C.; Verbrugge, F.H. Promise of SGLT2 Inhibitors in Heart Failure: Diabetes and Beyond. Curr. Treat. Options Cardiovasc. Med. 2017, 19, 23. [CrossRef] [PubMed]

123. Verdecchia, P.; Angeli, F.; Cavallini, C.; Aita, A.; Turturiello, D.; Reboldi, G. The revolution of the anti-diabetic drugs in cardiology. Eur. Hear. J. Suppl. 2020, 22, E162-E166. [CrossRef]

124. Braha, A.; Timar, B.; Diaconu, L.; Lupusoru, R.; Vasiluta, L.; Sima, A.; Vlad, A.; Munteanu, M.; Albai, A.; Cipu, D.; et al. Dynamics of Epicardiac Fat and Heart Function in Type 2 Diabetic Patients Initiated with SGLT-2 Inhibitors. Diabetes Metab. Syndr. Obes. Targets Ther. 2019, 12, 2559-2566. [CrossRef]

125. Zinman, B.; Wanner, C.; Lachin, J.M.; Fitchett, D.; Bluhmki, E.; Hantel, S.; Mattheus, M.; Devins, T.; Johansen, O.E.; Woerle, H.J.; et al. Empagliflozin, Cardiovascular Outcomes, and Mortality in Type 2 Diabetes. N. Engl. J. Med. 2015, 373, 2117-2128. [CrossRef] [PubMed]

126. Fitchett, D.; Inzucchi, S.E.; Cannon, C.P.; McGuire, D.K.; Scirica, B.M.; Johansen, O.E.; Sambevski, S.; Kaspers, S.; Pfarr, E.; George, J.T.; et al. Empagliflozin Reduced Mortality and Hospitalization for Heart Failure Across the Spectrum of Cardiovascular Risk in the EMPA-REG OUTCOME Trial. Circulation 2019, 139, 1384-1395. [CrossRef]

127. Furtado, R.H.; Bonaca, M.P.; Raz, I.; Zelniker, T.A.; Mosenzon, O.; Cahn, A.; Kuder, J.; Murphy, S.A.; Bhatt, D.L.; Leiter, L.A.; et al. Dapagliflozin and Cardiovascular Outcomes in Patients with Type 2 Diabetes Mellitus and Previous Myocardial Infarction. Circulation 2019, 139, 2516-2527. [CrossRef] [PubMed]

128. Wiviott, S.D.; Raz, I.; Bonaca, M.P.; Mosenzon, O.; Kato, E.; Cahn, A.; Silverman, M.G.; Bansilal, S.; Bhatt, D.L.; Leiter, L.A.; et al. The design and rationale for the Dapagliflozin Effect on Cardiovascular Events (DECLARE)-TIMI 58 Trial. Am. Heart J. 2018, 200, 83-89. [CrossRef] [PubMed]

129. Kohan, D.E.; Fioretto, P.; Tang, W.; List, J.F. Long-term study of patients with type 2 diabetes and moderate renal impairment shows that dapagliflozin reduces weight and blood pressure but does not improve glycemic control. Kidney Int. 2014, 85, 962-971. [CrossRef]

130. Fioretto, P.; Stefansson, B.V.; Johnsson, E.; Cain, V.A.; Sjöström, C.D. Dapagliflozin reduces albuminuria over 2 years in patients with type 2 diabetes mellitus and renal impairment. Diabetologia 2016, 59, 2036-2039. [CrossRef]

131. Neal, B.; Perkovic, V.; Mahaffey, K.W.; De Zeeuw, D.; Fulcher, G.; Erondu, N.; Shaw, W.; Law, G.; Desai, M.; Matthews, D.R.; et al. Canagliflozin and Cardiovascular and Renal Events in Type 2 Diabetes. N. Engl. J. Med. 2017, 377, 644-657. [CrossRef]

132. Perkovic, V.; de Zeeuw, D.; Mahaffey, K.W.; Fulcher, G.; Erondu, N.; Shaw, W.; Barrett, T.D.; Weidner-Wells, M.; Deng, H.; Matthews, D.R.; et al. Canagliflozin and renal outcomes in type 2 diabetes: Results from the CANVAS Program randomised clinical trials. Lancet Diabetes Endocrinol. 2018, 6, 691-704. [CrossRef]

133. Mahaffey, K.W.; Neal, B.; Perkovic, V.; de Zeeuw, D.; Fulcher, G.; Erondu, N.; Shaw, W.; Fabbrini, E.; Sun, T.; Li, Q.; et al. Canagliflozin for Primary and Secondary Prevention of Cardiovascular Events. Circulation 2018, 137, 323-334. [CrossRef]

134. Kluger, A.Y.; Tecson, K.M.; Barbin, C.M.; Lee, A.Y.; Lerma, E.; Rosol, Z.P.; Rangaswami, J.; Lepor, N.E.; Cobble, M.E.; McCullough, P.A. Cardiorenal Outcomes in the CANVAS, DECLARE-TIMI 58, and EMPA-REG OUTCOME Trials: A Systematic Review. Rev. Cardiovasc. Med. 2018, 19, 41-49. [CrossRef]

135. Strain, W.D.; Hope, S.; Green, A.; Kar, P.; Valabhji, J.; Sinclair, A.J. Type 2 diabetes mellitus in older people: A brief statement of key principles of modern day management including the assessment of frailty. A national collaborative stakeholder initiative. Diabet. Med. 2018, 35, 838-845. [CrossRef]

136. Buse, J.B.; Wexler, D.J.; Tsapas, A.; Rossing, P.; Mingrone, G.; Mathieu, C.; D'Alessio, D.A.; Davies, M.J. 2019 update to: Management of hyperglycaemia in type 2 diabetes, 2018. A consensus report by the American Diabetes Association (ADA) and the European Association for the Study of Diabetes (EASD). Diabetologia 2019, 63, 221-228. [CrossRef] [PubMed]

137. Gerstein, H.C.; Miller, E.M.; Byington, R.P.; Goff, D.C.; Bigger, J.T.; Buse, J.B.; Cushman, W.C.; Genuth, S.; Ismailbeigi, F.; Grimm, R.H.; et al. Effects of Intensive Glucose Lowering in Type 2 Diabetes. N. Engl. J. Med. 2008, 358, 2545-2559. [CrossRef] [PubMed]

138. Wysham, C.; Bhargava, A.; Chaykin, L.; De La Rosa, R.; Handelsman, Y.; Troelsen, L.N.; Kvist, K.; Norwood, P. Effect of Insulin Degludec vs Insulin Glargine U100 on Hypoglycemia in Patients With Type 2 Diabetes. JAMA 2017, 318, 45-56. [CrossRef] [PubMed]

139. Eriksson, J.G.; Laine, M.K. Insulin therapy in the elderly with type 2 diabetes. Minerva Endocrinol. 2015, 40, $283-295$. 